\title{
UPAYA MENINGKATKAN KEMAMPUAN MOTORIK HALUS ANAK MELALUI KEGIATAN MONTASE DI KELOMPOK B1 PAUD ISLAM TERPADU ANAK MANDIRI KOTA PALU
}

\author{
Nurhikma ${ }^{1)}$ Marwany $^{2)}$ Rustam $^{3)}$ \\ ${ }^{1}$ Mahasiswa Program Studi PIAUD FTIK Institut Agama Islam Negeri Palu \\ ${ }^{2}$ Dosen Fakultas Tarbiyah dan Ilmu Keguruan, Institut Agama Islam Negeri Palu \\ ${ }^{3}$ Dosen Fakultas Tarbiyah dan Ilmu Keguruan, Institut Agama Islam Negeri Palu
}

\begin{abstract}
ABSTRAK
Penelitian ini bertujuan untuk mengetahui penerapan kegiatan montase dapat meningkatkan kemampuan motorik halus anak khususnya di kelompok B1 PAUD Islam Terpadu Anak Mandiri serta untuk mengetahui adanya peningkatan kemampuan motorik halus anak di kelompok B1 PAUD Islam Terpadu Anak Mandiri Kota Palu. Penelitian ini menggunakan metode penelitian tindakan kelas (PTK). Teknik pengumpulan data dilakukan melalui lembar observasi, dokumentasi, dan wawancara. Hasil penelitian menunjukkan bahwa kemampuan motorik halus anak meningkat setelah adanya tindakan melalui penggunaan kegiatan montase. Pada saat dilakukan observasi pra tindakan, presentasi kemampuan motorik halus sebesar $8.33 \%$ kemudian mengalami peningkatan pada siklus I tindakan I $22.22 \%$, kemudian meningkat pada siklus I tindakan II $30.55 \%$. Pada pelaksanaan siklus II juga mengalami peningkatan $72.22 \%$ dan kemudian terjadi peningkatan yang sangat baik pada siklus II tindakan II 83.33\% Implikasi dari penelitian ini yaitu guru disarankan selalu menggunakan pendekatan pembelajaran yang lebih bervariatif, sehingga tidak menimbulkan kebosanan pada anak.
\end{abstract}

Kata Kunci : Motorik halus, Anak usia dini, Kegiatan Montase

\section{PENDAHULUAN}

Pendidikan adalah usaha sadar dan sistematis untuk mewujudkan suasana belajar dan proses pembelajaran agar peserta didik dapat mengembangkan potensi dirinya secara aktif untuk memiliki pengendalian diri, kecerdasan, keterampilan dalam masyarakat. Pada hakikatnya pendidikan anak usia dini diselenggarakan dengan tujuan untuk memfasilitasi pertumbuhan dan perkembangan anak sesuai dengan keunikan dan tahaptahap perkembangan yang akan dilalui oleh masing-masing anak. Pada dasarnya anak usia dini berbeda dari orang dewasa, untuk itu mereka perlu dipahami dan diberikan perhatian serta bimbingan khusus. Sebagaimana terjemahan surah Al-Luqman ayat 13 yaitu: 


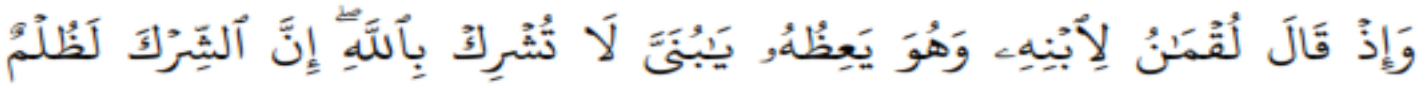 \\ 수요}

Terjemahnya:

"Dan (ingatlah) ketika Luqman berkata kepada anaknya, di waktu ia memberi pelajaran kepadanya: "Hai anakku, janganlah kamu mempersekutukan Allah, Sesungguhnya mempersekutukan (Allah) adalah benar-benar kezaliman yang besar". ${ }^{1}$

Usia dini merupakan usia ketika anak mengalami pertumbuhan dan perkermbangan yang pesat. Usia dini juga merupakan priode awal yang paling penting dan mendasar dalam rentang pertumbuhan serta perkembangan kehidupan manusia. Dalam UndangUndang No. 20 Tahun 2003 tentang Sistem Pendidikan Nasional Bab 1 pasal 1 ayat 14 dinyatakan bahwa:

Pendidikan anak usia dini adalah suatu upaya pembinaan yang ditujukan kepada anak sejak lahir sampai dengan usia enam tahun yang dilakukan melalui pemberian rangsangan pendidikan untuk membantu pertumbuhan dan perkembangan jasmani dan rohani agar anak memiliki kesiapan dalam memasuki pendidikan lebih lanjut. ${ }^{2}$

Anak usia dini adalah anak yang berada pada rentan usia 0 hingga 6 tahun, pada masa ini anak sangat membutuhkan pendidikan yang dapat membantu pertumbuhan, khususnya kesiapan masuk sekolah untuk mengikuti kegiatan pembelajaran. Beberapa orang menyebut fase ini sebagai golden age atau masa keemasan karena masa ini sangat menentukan. Masa ini juga merupakan masa yang paling potensial untuk belajar oleh karena itu pelaksanaan pendidikan anak usia dini harus berkualitas dan sesuai dengan perkembangan anak itu sendiri.

Salah satu kemampuan yang terlihat pada masa usia dini yaitu: perkembangan motorik halusnya yang melibatkan otot kecil serta koordinasi mata dan tangan misalnya: kemampuan menggunting, menempel, menganyam, kemampuan meremas-remas, menyusun balok, membuat garis, melipat kertas dan sebagainya. Kemampuan motorik halus adalah gerakan yang hanya melibatkan bagian-bagian tubuh tertentu saja dan dilakukan oleh otot-otot kecil, serta memerlukan koordinasi mata oleh karna itu tidak terlalu memerlukan tenaga. Tingkat pencapaian perkembangan motorik halus anak usia 5-6 tahun dalam PERMENDIKBUD Nomor 137 Tahun 2014 yaitu:

Menggambar sesuai gagasannya, meniru bentuk, melakukan eksplorasi dengan berbagai media dan kegiatan, menggunakan alat tulis dan alat makan

\footnotetext{
${ }^{1}$ Departemen Agama RI, AL-Qur'an dan Terjemah, Surabaya: Fajar Mulya, 2012.

2 Leli Halimah, Pengembangan Kurikulum Pendidikan Anak Usia dini. (Cet. 1; Jl. Mengger Girang No. 98, Bandung: PT Refika Aditama, 2016), 14.
} 
dengan benar, menggunting sesuai dengan pola, menempel gambar dengan tepat, mengepresikan diri melalui gerakan menggambar secara rinci. ${ }^{3}$

Kemampuan motorik halus anak di kelompok B1 PAUD Islam terpadu anak mandiri Kota Palu, dapat dilihat pada proses pembelajaran yang berlangsung. Terdapat beberapa anak yang perkembangan motorik halusnya masih mengalami kesulitan antara koordinasi mata dan tangan misalnya, belum baik dalam merwarnai gambar, melipat kertas, dan menggunting, yang disebabkan oleh kurangnya kegiatan-kegiatan yang mampu mengembangkan kemampuan motorik halus anak.

Alasan peneliti memilih kegiatan montase dibandingkan kegiatan motorik halus lainnya, karena kegiatan montase masih sangat jarang diterapkan di Taman Kanak-kanak lainnya, selain itu pula kegiatan montase merupakan kegiatan menggunting gambar kemudian ditempel pada suatu bidang, maka melalui kegiatan montase anak dapat berkarya dan memperoleh pengalaman baru, anak juga dapat mengembangkan kemampuan motorik halusnya. Montase yaitu suatu karya seni yang dihasilkan dari potongan-potongan gambar kemudian ditempelkan pada suatu bidang sehingga menjadi suatu karya dua atau tiga dimensi. ${ }^{4}$ Sebelum memulai kegiatan pembelajaran, diawal akan dijelaskan dan diberi contoh dari guru tentang cara dalam membuat montase, agar anak tahu apa yang akan mereka lakukan, kemudian guru membagikan lembaran kerja yang memuat gambar yang akan digunting dan ditempelkan pada lembaran kosong. Selanjutnya, kegiatan terakhir adalah mengamati dan membimbing anak secara langsung.

Berdasarkan uraian di atas, maka tujuna penelitian ini adalah untuk mengetahui penerapan kegiatan montase dapat meningkatkan kemampuan motorik halus anak khususnya di kelompok B1 PAUD Islam Terpadu Anak Mandiri Kota Palu serta untuk mengetahui adanya peningkatan kemampuan motorik halus anak di kelompok B1 PAUD Islam Terpadu Anak Mandiri Kota Palu.

\section{METODE PENELITIAN}

Penelitian ini adalah jenis penelitian tindakan. Melalui penelitian tindakan, peneliti melakukan penelitian terhadap upaya meningkatkan kemampuan motorik halus anak melalui kegiatan montase. Pelaksanaan penelitian tindakan ini mempunyai tahapan yang bersiklus. Rancangan penelitian ini mengaju pada siklus pelaksanaan penelitian tindakan model John Elliot, seperti pada gambar tiap siklus dilakukan beberapa tahap, yaitu 1) Perencanaan Tindakan, 2) Pelaksanaan Tindakan 3) Observasi, dan 4) Refleksi. ${ }^{5}$

\footnotetext{
${ }^{3}$ PERMENDIKBUD nomor 137 tahun 2014, Tentang Standar Nasional Pendidikan Anak Usia Dini

${ }^{4}$ Novidewi Ayusari, Keterampilan Montase. (Cet. 1; Yogyakarta: Indopublika, 2017), 1.

${ }^{5}$ Mahmud, Motode Penelitian Pendidikan. (Bandung: Pustaka setia, 2011), 221
} 


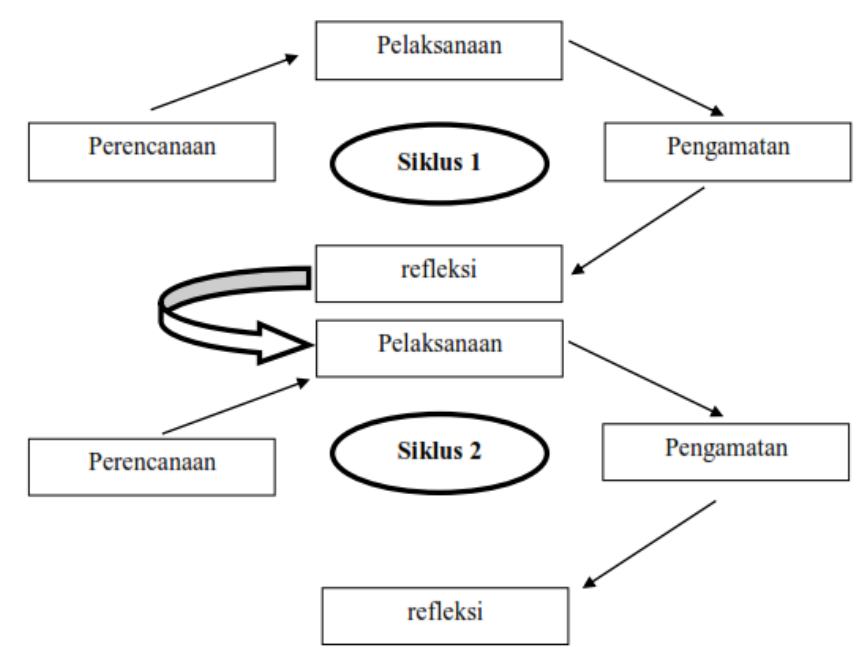

Gambar 1. Siklus PTK Model Elliot

Penelitian ini dilakukan di PAUD Islam Terpadu Anak Mandiri terletak di jalan Mas Mansyur Kelurahan Lere Kecamatan Palu Barat Kota Palu. Subyek penelitian ini adalah anak kelompok B1 PAUD Islam Terpadu Anak Mandiri Kota Palu. Yang berjumlah 12 anak terdiri dari 7 anak laki-laki dan 5 anak perempuan.

Teknik pengumpulan data yang digunakan dalam pelaksanaan penelitian ini meliputi teknik observasi, dokumentasi dan wawancara. Analisis data dilakukan oleh peneliti terhadap hasil pengamatan yang diperoleh melalui lembar observasi pada siklus I. Setelah data terkumpul, lalu dianalisis secara kualitatif dan kuantitatif untuk mengetahui proses tindakan. Selanjutnya dinarasikan untuk mengambil kesimpulan tentang ada tidaknya peningkatan kemampuan motorik halus pada anak usia dini melalui kegiatan montase dengan menggunakan pedoman dari Direktorat Jendral Departemen Pendidikan Nasional $2010^{6}$ dengan kriteria sebagai berikut:

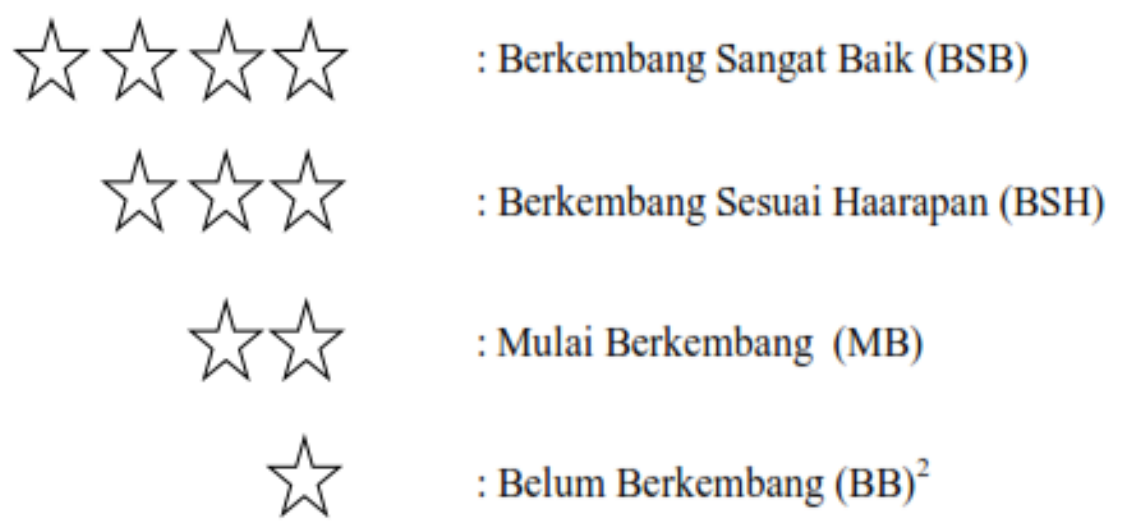

\footnotetext{
${ }^{6}$ Johni Dimyati, Metodologi Penelitian Pendidikan dan Aplikasi pada Pendidikan Anak Usia Dini (PAUD). (cet. 2; Jakarta: Kencana, 2014), 96Motode Penelitian Pendidikan. (Bandung: Pustaka setia, 2011), 221
} 


\section{HASIL DAN PEMBAHASAN}

Pada penelitian ini, peneliti akan memaparkan hasil penelitian tindakan kelas yang dilakukan oleh peneliti di PAUD Islam Terpadu anak mandiri Kota Palu untuk meningkatkan kemampuan motorik halus peserta didik dengan kegiatan montase. Peneliti akan menguraikan dibawah ini, tentang hasil penelitian yang didapatkan dari pra tindakan, siklus I, dan siklus II.

\section{Pra Tindakan}

Langkah awal dari penelitian ini, peneliti melakukan observasi awal untuk melihat sejauh mana kemampuan motorik halus peserta didik. Kegiatan pra tindakan umumnya dilakukan sebelum peneliti memulai penelitian terhadap upaya meningkatkan kemampuan motorik halus anak melalui kegiatan montase di kelompok B1 PAUD Islam Terpadu Anak Mandiri Kota Palu.

Pada saat pra tindakan dilakukan oleh peneliti dikelompok B1 peserta didik yang hadir berjumlah 12 peserta didik. Adapun peningkatan kemampuan motorik halus anak menggunakan media gambar yang digunting yang peneliti amati di kelompok B1 yaitu: peserta didik sudah bisa dalam menggunting dengan bantuan guru, ketepatan anak dalam menggunting dan koordinasi mata dan tangan.

Dari hasil pengamatan dapat dijelaskan bahwa dari 12 peserta didik di kelompok B1 PAUD Islam Terpadu anak mandiri Kota Palu, yang menjadi subyek penelitian untuk peningkatan kemampuan motorik halus dalam aspek kekuatan jari jemari dalam menggunting, terdapat 1 peserta didik $(8.33 \%)$ dalam kategori berkembang sangat baik (BSB), ada 2 peserta didik (16.67\%) dalam kategori berkembang sesuai harapan (BSH), ada 2 peserta didik (16.67\%) dalam kategori mulai berkembang (MB), dan ada 7 peserta didik $(58.33 \%)$ dalam kategori ini belum berkembang (BB).

Selanjutnya dapat dijelaskan bahwa dari 12 peserta didik di kelompok B1 PAUD Islam Terpadu anak mandiri Kota Palu, yang menjadi subyek penelitian untuk peningkatan kemampuan motorik halus dalam aspek ketepatan anak dalam menempel, terdapat 1 peserta didik (8.33\%) dalam kategori berkembang sangat baik (BSB), ada 1 peserta didik (8.33\%) dalam kategori berkembang sesuai harapan (BSH), ada 5 peserta didik (41.67\%) dalam kategori mulai berkembang (MB), dan ada 5 peserta didik (41.67\%) dalam kategori ini belum berkembang (BB).

Adapun data peningkatan kemampuan motorik halus dalam aspek koordinasi mata dan tangan peserta didik di kelompok B1 PAUD Islam Terpadu anak mandiri Kota Palu, yakni terdapat 1 peserta didik (8.34\%) dalam kategori berkembang sangat baik (BSB), ada 1 peserta didik (8.33\%) dalam kategori berkembang sesuai harapan (BSH), ada 3 peserta didik (25\%) dalam kategori mulai berkembang (MB), dan ada 7 peserta didik $(58.33 \%)$ dalam kategori ini belum berkembang (BB).

Setelah dirata-ratakan ketiga aspek yang diamati terdapat $8.33 \%$ dalam kategori berkembang sangat baik (BSB), 11,11\% dalam kategori berkembang sesuai harapan (BSH), $27.78 \%$ dalam kategori ini mulai berkembang (MB), dan $52.78 \%$ dalam kategori belum berkembang (BB). Berdasarkan hasil nilai rata-rata yang telah dijelaskan pada pra tindakan di kelompok B1 dapat dilihat sebagian besar 52.78\% peserta didik dikategorikan 
belum berkembang dalam kemampuan motorik halus anak melalui kegiatan montase, sedangkan dalam kategori berkembang sangat baik terdapat $8.33 \%$, oleh karena itu peneliti melakukan penelitian untuk tindakan kelas.

\section{Hasil Pengamatan Siklus I}

Pada tahapan di siklus I, peneliti melakukan proses belajar dan mengajar di dalam kelas berdasarkan RPPH yang telah dibuat. Di dalam tahapan siklus I ini, peneliti melakukan 2 kali pertemuan di kelompok B1 untuk meningkatkan kemampuan motorik halus anak melalui kegiatan montase. Peneliti melakukan tindakan I dan tindakan II pada siklus I, dimulai membuat perencanaan, pelaksanaan, observasi, dan refleksi. Saat penyajian materi, peneliti bertindak sebagai pengajar atau guru.

Perencanaan tindakan pada siklus I, meliputi menentukan tema dan tujuan pembelajaran, membuat rencana program pembelajaran harian (RPPH), menyediakan media pembelajaran, membuat rubrik penilaian upaya meningkatkan kemampuan motorik halus anak melalui kegiatan montase dan membuat lembaran penilaian dalam meningkatkan kemampuan motorik halus anak melalui kegiatan montase.

Peneliti melaksanakan proses pembelajaran di dalam kelas berdasarkan RPPH yang telah dibuat yaitu: melaksanakan kegiatan pembukaan, kegiatan inti, istirahat, dan kegiatan akhir. Selanjutnya peneliti melakukan pengamatan terhadap aktivitas peserta didik pada saat proses kegiatan pembelajaran berlangsung.

Berdasarkan pengamatan yang dilakukan pada tindakan I, diketahui dari 12 anak dalam kekuatan jari jemari dalam menggunting terdapat 3 peserta didik (25\%) dalam kategori ini berkembang sangat baik (BSB), 3 peserta didik (25\%) dalam kategori ini berkembang sesuai harapan (BSH), 4 peserta didik (33.33\%) dalam kategori ini mulai berkembang (MB), dan 2 peserta didik (16.67\%) dalam kategori ini belum berkembang (BB). Ketepatan anak dalam menempel terdapat 3 peserta didik (25\%) dalam kategori ini berkembang sangat baik (BSB), 3 peserta didik (25\%) dalam kategori ini berkembang sesuai harapan (BSH), 5 peserta didik $(41.67 \%)$ dalam kategori ini mulai berkembang (MB), dan 1 peserta didik (8.33\%) dalam kategori ini belum berkembang (BB). Koordinasi mata dan tangan terdapat 2 peserta didik (16.67\%) dalam kategori ini berkembang sangat baik (BSB), 4 peserta didik (33.33\%) dalam kategori ini berkembang sesuai harapan (BSH), 3 peserta didik (25\%) dalam kategori ini mulai berkembang (MB), dan 3 peserta didik (25\%) dalam kategori ini belum berkembang (BB).

Dalam tindakan II, diketahui dari 12 anak dalam kekuatan jari jemari dalam menggunting melalui tindakan II terdapat 5 peserta didik (41.67\%) dalam kategori ini berkembang sangat baik (BSB), 1 peserta didik (8.33\%) dalam kategori ini berkembang sesuai harapan (BSH), 6 peserta didik (50\%) dalam kategori ini mulai berkembang (MB), dan 0 peserta didik $(0 \%)$ tidak terdapat dalam kategori ini belum berkembang (BB). Ketepatan anak dalam menempel terdapat 4 peserta didik (33.33\%) dalam kategori ini berkembang sangat baik (BSB), 3 peserta didik (25\%) dalam kategori ini berkembang sesuai harapan $(\mathrm{BSH}), 5$ peserta didik $(41.67 \%)$ dalam kategori ini mulai berkembang (MB), dan 0 peserta didik (0\%) tidak terdapat dalam kategori ini belum berkembang (BB). Koordinasi mata dan tangan terdapat 2 peserta didik (16.66\%) dalam kategori ini 
berkembang sangat baik (BSB), 5 peserta didik (41.67\%) dalam kategori ini berkembang sesuai harapan (BSH), 5 peserta didik (41.67\%) dalam kategori ini mulai berkembang (MB), dan 0 peserta didik (0\%) tidak terdapat dalam kategori ini belum berkembang (BB).

Berdasarkan rekapitulasi, dirata-ratakan ketiga aspek yang diamati dari tindakan I dan II dari siklus I di kelompok B1. Hasil tindakan I terdapat 22.22\% dalam kategori berkembang sangat baik (BSB), 27.77\% dalam kategori berkembang sesuai harapan (BSH), 33.34\% dalam kategori mulai berkembang (MB), 16.67\% dalam kategori belum berkembang (BB). Hasil dari tindakan II terdapat 30.55\% dalam kategori berkembang sangat baik (BSB), 25\% dalam kategori berkembang sesuai harapan (BSH), $44.45 \%$ dalam kategori mulai berkembang (MB), dan $0 \%$ tidak terdapat dalam kategori belum berkembang (BB).

Melihat hasil persentase pengamatan tindakan I dan II pada siklus I di kelompok B1 terhadap upaya meningkatkan kemampuan motorik halus anak melalui kegiatan montase, jelas terlihat bahwa persentase yang diperoleh dari 3 aspek pengamatan meningkatkan kemampuan motorik halus anak yang dinilai dalam kekuatan jari jemari dalam mengguntinng, ketepatan anak dalam menempel, koordinasi mata dan tangan, telah ada peningkatan dari siklus I tindakan I yaitu 22.22\% dalam kategori berkembang sangat baik dan tindakan II 30.55\%. Namun peneliti ingin meningkatkan kembali kemampuan motorik halus anak melalui kegiatan montase menjadi $80 \%$ dalam kategori berkembang sangat baik (BSB). Berdasarkan hasil tersebut, peneliti melakukan tindakan siklus II.

Berdasarkan hasil pengamatan peneliti yang dilakukan pada aktivitas guru yang masuk dalam kategori yang harus ditingkatkan untuk mencapai kriteria keberhasilan yang baik. Sedangkan aktivitas peserta didik sekalipun sudah dapat peningkatan dari hasil pra tindakan, sedangkan pada siklus I tindakan I sudah mulai mencapai persentase keberhasilan tindakan. Namun hasil yang diharapkan belum sesuai dengan tujuan penelitian, yaitu untuk meningkatkan kemampuan motorik halus anak melalui kegiatan montase dalam kategori berkembang sangat baik dengan persentase $80 \%$ yang dicapai. Hal ini disebabkan karena masih ada beberapa anak yang masuk dalam kategori mulai berkembang dalam ketiga aspek pengamatan dalam kekuatan jari jemari dalam menggunting, ketepatan anak dalam menempel, dan koordinasi mata dan tangan. Selain itu ada temuan-temuan atau kejadian yang didapatkan selama tindakan berlangsung yang menjadi kelemahan dan perlu diperbaiki pada perencanaan tindakan selanjutnya di Paud Islam Terpadu anak mandiri Kota Palu.

Tabel 1. Refleksi Tindakan Siklus I Upaya Meningkatkan Kemampuan Motorik Halus Anak Melalui Kegiatan Montase

\begin{tabular}{|l|l|l|}
\hline \multicolumn{1}{|c|}{ Kelemahan } & \multicolumn{1}{|c|}{ Analisis Penyebab } & \multicolumn{1}{c|}{ Rekomendasi } \\
\hline Kekuatan jari jemari dalam & Disebabkan oleh anak masih & Guru / peneliti menerapkan \\
menggunting, ketepatan anak & merasa bingung serta kaku & kegiatan montase agar \\
dalam menempel, dan & dalam menggunting dan & kekuatan jari jemari dalam \\
koordinasi mata dan tangan & menempel suatu gambar yang & menggunting, ketepatan anak \\
sudah cukup baik tetapi lebih & sesuai dengan pola. & dalam menempel, dan \\
ditingkatkan lagi & & koordinasi mata dan tangan \\
& & \\
\hline
\end{tabular}

\section{Hasil Pengamatan Siklus II}


Pada tahapan disiklus II ini, peneliti malakukan proses belajar dan mengajar di dalam kelas berdasarkan RPPH yang telah dibuat. Di dalam tahapan siklus II ini, peneliti melakukan 2 kali pertemuan di kelompok B1 untuk meningkatkan kemampuan motorik halus anak melalui kegiatan montase. Peneliti melakukan tindakan I dan tindakan II pada siklus II, dimulai membuat perencanaan, pelaksanaan, observasi, dan refleksi. Saat penyajian materi, peneliti bertindak sebagai pengajar atau guru.

Kegiatan perencanaan tindakan pada siklus II meliputi menentukan tema dan tujuan pembelajaran, membuat rencana program pembelajaran harian (RPPH), menyediakan media pembelajaran, membuat rubrik penilaian meningkatkan kemampuan motorik halus anak melalui kegiatan montase, serta membuat lembaran penilaian dalam perkembangan motorik halus anak melalui kegiatan montase.

Peneliti melaksanakan proses pembelajaran di dalam kelas berdasarkan RPPH yang telah dibuat yaitu: melaksanakan kegiatan pembukaan, kegiatan inti, istirahat, dan kegiatan akhir. Selanjutnya peneliti melakukan pengamatan terhadap aktivitas peserta didik pada saat proses kegiatan pembelajaran berlangsung.

Berdasarkan hasil pengamatan pada tindakan I dalam siklus II, diketahui dari 12 anak dalam kekuatan jari jemari dalam menggunting melalui tindakan I terdapat 9 peserta didik (75\%) dalam kategori ini berkembang sangat baik (BSB), 3 peserta didik (25\%) dalam kategori ini berkembang sesuai harapan (BSH), 0 peserta didik $(0 \%)$ tidak terdapat dalam kategori ini mulai berkembang (MB), dan 0 peserta didik (0\%) tidak terdapat dalam kategori ini belum berkembang (BB). Pada indikator, Ketepatan anak dalam menempel terdapat 10 peserta didik (83.33\%) dalam kategori ini berkembang sangat baik (BSB), 2 peserta didik (16.67\%) dalam kategori ini berkembang sesuai harapan (BSH), 0 peserta didik $(0 \%)$ tidak terdapat dalam kategori ini mulai berkembang (MB), dan 0 peserta didik $(0 \%)$ tidak terdapat dalam kategori ini belum berkembang (BB). Koordinasi mata dan tangan terdapat 7 peserta didik $(58.33 \%)$ dalam kategori ini berkembang sangat baik (BSB), 5 peserta didik (41.67\%) dalam kategori ini berkembang sesuai harapan (BSH), 0 peserta didik $(0 \%)$ tidak terdapat dalam kategori ini mulai berkembang (MB), dan 0 peserta didik (0\%) tidak terdapat dalam kategori ini belum berkembang (BB).

Dalam tindakan II, diketahui dari 12 anak dalam kekuatan jari jemari dalam menggunting melalui tindakan II terdapat 10 peserta didik $(83.33 \%)$ dalam kategori ini berkembang sangat baik (BSB), 2 peserta didik (16.67\%) dalam kategori ini berkembang sesuai harapan $(\mathrm{BSH}), 0$ peserta didik $(0 \%)$ tidak terdapat dalam kategori ini mulai berkembang (MB), dan 0 peserta didik $(0 \%)$ tidak terdapat dalam kategori ini belum berkembang (BB). Ketepatan anak dalam menempel terdapat 11 peserta didik $(91.67 \%)$ dalam kategori ini berkembang sangat baik (BSB), 1 peserta didik (8.33\%) dalam kategori ini berkembang sesuai harapan (BSH), 0 peserta didik $(0 \%)$ tidak terdapat dalam kategori ini mulai berkembang (MB), dan 0 peserta didik $(0 \%)$ tidak terdapat dalam kategori ini belum berkembang (BB). Koordinasi mata dan tangan terdapat 9 peserta didik $(75 \%)$ dalam kategori ini berkembang sangat baik (BSB), 3 peserta didik $(25 \%)$ dalam kategori ini berkembang sesuai harapan (BSH), 0 peserta didik $(0 \%)$ tidak terdapat dalam kategori 
ini mulai berkembang (MB), dan 0 peserta didik $(0 \%)$ tidak terdapat dalam kategori ini belum berkembang (BB).

Berdasarkan hasil rekapitulasi, dirata-ratakan ketiga aspek yang diamati dari tindakan I dan II dari siklus II di kelompok B1. Hasil tindakan I terdapat $72.22 \%$ dalam kategori berkembang sangat baik (BSB), 27.78\% dalam kategori berkembang sesuai harapan (BSH), 0\% dalam kategori mulai berkembang (MB), 0\% dalam kategori belum berkembang (BB). Hasil dari tindakan II terdapat $83.33 \%$ dalam kategori berkembang sangat baik (BSB), 16.67\% dalam kategori berkembang sesuai harapan (BSH), 0\% dalam kategori mulai berkembang (MB), dan 0\% dalam kategori belum berkembang (BB). Melihat hasil persentase pengamatan tindakan I dan II pada siklus II di kelompok B1 terhadap upaya meningkatkan kemampuan motorik halus anak melalui kegiatan montase, jelas terlihat bahwa persentase yang diperoleh dari 3 aspek pengamatan meningkatkan kemampuan motorik halus anak yang dinilai dalam kekuatan jari jemari dalam menggunting, ketepatan anak dalam menempel, koordinasi mata dan tangan, telah ada peningkatan dari siklus II tindakan I yaitu $72.22 \%$ dalam kategori berkembang sangat baik dan tindakan II $83.33 \%$. Hasil persentase tindakan II pada siklus II telah mencapai keberhasilan yang diharapkan peneliti. Oleh karena itu, tidak perlu dilakukan perbaikan pada tindakan selanjutnya. Hal ini menunjukkan bahwa kegiatan montase berperan penting dalam meningkatkan kemampuan motorik halus anak.

Berdasarkan hasil pengamatan yang dilakukaan oleh peneliti pada aktivitas guru yang masuk pada kategori baik yang diamati telah masuk dalam kategori baik, sedangkan aktivitas anak dalam proses pembelajaran telah mencapai persentase keberhasilan dalam tindakan ketiga aspek pengamatan, yaitu kekuatan jari jemari dalam menggunting, ketepatan anak dalam menempel, dan koordinasi mata dan tangan, kegiatan montase yang telah diterapkan oleh guru dalam proses pembelajaran telah meningkatkan kemampuan motorik halus anak melalui kegiatan montase di kelompok B1 PAUD Islam Terpadu anak mandiri Kota Palu.

Tabel 2. Refleksi Tindakan Siklus II Upaya Meningkatkan Kemampuan Motorik Halus Anak Melalui Kegiatan Montase

\begin{tabular}{|l|l|l|}
\hline No & \multicolumn{1}{|c|}{ Temuan } & \multicolumn{1}{|c|}{ Analisis Penyebab } \\
\hline 1 & $\begin{array}{l}\text { Anak sudah dapat meningkatkan } \\
\text { kemampuan motorik halus dalam } \\
\text { kekuatan jari jemari dalam } \\
\text { menggunting, ketepatan anak dalam } \\
\text { menempel, dan koordinasi mata dan } \\
\text { tangan. }\end{array}$ & $\begin{array}{l}\text { Guru atau peneliti selalu mendampingi anak } \\
\text { selama kegiatan montase berlangsung, } \\
\text { mengajarkan bagaimana cara menggunting } \\
\text { yang mudah dan cara menempel yang baik. }\end{array}$ \\
\hline 2 & $\begin{array}{l}\text { Sebagian besar anak tidak ada lagi yang } \\
\text { tidak bisa dalam menggunting dan } \\
\text { menempel, dalam hal ini kekuatan jari } \\
\text { jemari dalam menggunting, ketepatan } \\
\text { anak dalam menempel serta koordinasi } \\
\text { mata dan tangan anak telah meningkat. }\end{array}$ & $\begin{array}{l}\text { Anak sangat senang menerima pembelajaran } \\
\text { melalui kegiatan montase, dan begitu antusias } \\
\text { dalam menerima materi }\end{array}$ \\
\hline
\end{tabular}


Persentase yang diperoleh dari hasil pengamatan tindakan siklus II di kelompok B1 jelas terlihat bahwa persentase yang diperoleh dari tiga aspek pengamatan peningkatan kemampuan motorik halus anak melalui kegiatan montase dalam aspek kekuatan jari jemari dalam menggunting, ketepatan anak dalam menempel, dan koordinasi mata dan tangan, telah mencapai keberhasilan tindakan pada penelitian yang diharapkan oleh peneliti. Oleh karena itu, tidak perlu dilakukan perbaikan pada tindakan selanjutnya atau siklus 3. Sangat jelas terlihat perubahan kemampuan motorik halus anak mulai dari pra tindakan, anak yang masih butuh bantuan guru dalam hal menggunting serta menempel dikarenakan kurangnya latihan dalam hal menggunting dan menempel. Siklus I dan siklus II terlihat ada peningkatan melalui kegiatan montase, karena anak telah dapat menggunting serta menempel tanpa bantuan guru lagi yang artinya dalam kekuatan jari jemari dalam menggunting anak telah ada perubahan begitu pula dengan ketepatan anak dalam menempel dan koordinasi mata dan tangannya telah ada peningkatan. Hal ini menunjukkan bahwa melalui kegiatan montase berperan penting dalam meningkatkan kemampuan motorik halus anak.

Upaya meningkatkan kemampuan motorik halus anak melalui kegiatan montase pada siklus II mencapai keberhasilan karena peneliti senantiasa mendampingi peserta didik dalam menyelesaikan tugasnya, dan juga memotivasi serta selalu memberikan pujian kepada peserta didik. Selain itu, peneliti juga memberikan bintang sebagai bentuk reward buat peserta didik, dan mengajarkan anak agar tidak malas dalam mengikuti pembelajaran yang sedang berlangsung. Oleh karena itu, peneliti memutuskan untuk tidak melanjutkan ke tahap berikutnya atau siklus berikutnya, karena peserta didik yang belum berkembang persentasenya sangat kecil. Penelitian tindakan kelas ini, bisa dikatakan berhasil dengan baik karena telah dapat memperbaiki proses pembelajaran yang berdampak dengan meningkatnya kemampuan motorik halus anak melalui kegiatan montase di kelompok B1 PAUD Islam Terpadu anak mandiri Kota Palu.

\section{KESIMPULAN}

1. Bentuk penerapan kegiatan montase dikelompok B1 pada siklus I upaya meningkatkan kemampuan motorik halus anak melalui kegiatan montase pada tindakan I persentasenya yaitu $22.22 \%$ dalam kategori berkembang sangat baik (BSB) sedangkan pada tindakan II persentasenya yaitu $30.55 \%$ dalam kategori berkembang sangat baik (BSB) dan ada peningkatan pada siklus 1. Tetapi Hal tersebut belum mencapai sesuai harapan penulis untuk mencapai $80 \%$ dalam kategori berkembang sangat baik.

2. Hasil siklus II di kelompok B1 tindakan I persentasenya yaitu $72.22 \%$ dalam kategori berkembang sangat baik (BSB), sedangkan pada tindakan II siklus II persentasenya yaitu $83.33 \%$ dalam kategori berkembang sangat baik (BSB). Hal tersebut telah mencapai sesuai harapan penulis untuk mencapai $80 \%$ dalam kategori berkembang sangat baik. 


\section{DAFTAR PUSTAKA}

Ayusari, Novidewi. 2017. Keterampilan Montase (Cet. I). Yogyakarta: Indopublika.

Departemen Agama RI. 2012. AL-Qur'an dan Terjemah, Surabaya: Fajar Mulya.

Dimyati, Johni. 2014. Metodologi Penelitian Pendidikan dan Aplikasi pada Pendidikan Anak Usia Dini (PAUD). Jakarta: Kencana.

Halimah, Leli. 2016. Pengembangan Kurikulum Pendidikan Anak Usia dini. (Cet. 1; J1. Mengger Girang No. 98). Bandung: PT Refika Aditama.

Mahmud. 2011. Metode Penelitian Pendidikan. Bandung: Pustaka setia.

PERMENDIKBUD nomor 137 tahun 2014, Tentang Standar Nasional Pendidikan Anak Usia Dini 
